\title{
Front Matter: Volume 11097
}

, "Front Matter: Volume 11097," Proc. SPIE 11097, Organic and Hybrid FieldEffect Transistors XVIII, 1109701 (16 October 2019); doi: 10.1117/12.2551099 SPIE. Event: SPIE Organic Photonics + Electronics, 2019, San Diego, California, 


\title{
PROCEEDINGS OF SPIE
}

\section{Organic and Hybrid Field-Effect Transistors XVIII}

\author{
Iain McCulloch \\ Oana D. Jurchescu \\ Editors
}

\section{2-15 August 2019}

San Diego, California, United States

Sponsored by

SPIE

Cosponsored by

Millipore Sigma (United States)

Journal of Materials Chemistry C (United Kingdom)

Published by

SPIE 
The papers in this volume were part of the technical conference cited on the cover and title page. Papers were selected and subject to review by the editors and conference program committee. Some conference presentations may not be available for publication. Additional papers and presentation recordings may be available online in the SPIE Digital Library at SPIEDigitalLibrary.org.

The papers reflect the work and thoughts of the authors and are published herein as submitted. The publisher is not responsible for the validity of the information or for any outcomes resulting from reliance thereon.

Please use the following format to cite material from these proceedings:

Author(s), "Title of Paper," in Organic and Hybrid Field-Effect Transistors XVIII, edited by lain McCulloch, Oana D. Jurchescu, Proceedings of SPIE Vol. 11097 (SPIE, Bellingham, WA, 2019) Sevendigit Article CID Number.

ISSN: 0277-786X

ISSN: 1996-756X (electronic)

ISBN: 9781510628878

ISBN: 9781510628885 (electronic)

Published by

SPIE

P.O. Box 10, Bellingham, Washington 98227-0010 USA

Telephone +1 3606763290 (Pacific Time) · Fax +1 3606471445

SPIE.org

Copyright (c) 2019, Society of Photo-Optical Instrumentation Engineers.

Copying of material in this book for internal or personal use, or for the internal or personal use of specific clients, beyond the fair use provisions granted by the U.S. Copyright Law is authorized by SPIE subject to payment of copying fees. The Transactional Reporting Service base fee for this volume is $\$ 21.00$ per article (or portion thereof), which should be paid directly to the Copyright Clearance Center (CCC), 222 Rosewood Drive, Danvers, MA 01923. Payment may also be made electronically through CCC Online at copyright.com. Other copying for republication, resale, advertising or promotion, or any form of systematic or multiple reproduction of any material in this book is prohibited except with permission in writing from the publisher. The CCC fee code is 0277$786 \mathrm{X} / 19 / \$ 21.00$.

Printed in the United States of America by Curran Associates, Inc., under license from SPIE.

Publication of record for individual papers is online in the SPIE Digital Library.

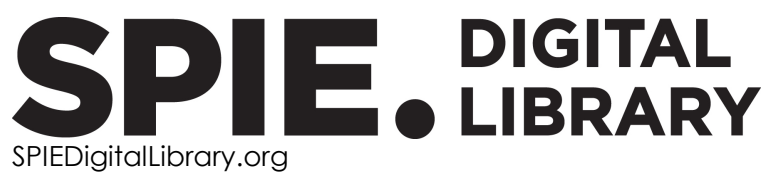

Paper Numbering: Proceedings of SPIE follow an e-First publication model. A unique citation identifier (CID) number is assigned to each article at the time of publication. Utilization of CIDs allows articles to be fully citable as soon as they are published online, and connects the same identifier to all online and print versions of the publication. SPIE uses a seven-digit CID article numbering system structured as follows:

- The first five digits correspond to the SPIE volume number.

- The last two digits indicate publication order within the volume using a Base 36 numbering system employing both numerals and letters. These two-number sets start with $00,01,02,03,04$, 05, 06, 07, 08, 09, 0A, OB ... 0Z, followed by 10-1Z, 20-2Z, etc. The CID Number appears on each page of the manuscript. 


\section{Contents}

$\begin{array}{ll}\vee & \text { Authors } \\ \text { vii } & \text { Conference Committee }\end{array}$

OFETs

1109707 Efficient interface engineering for high-performance fully inkjet-printed organic thin-film devices via functionalized polystyrene interlayers [1 1097-5]

DEVICE PHYSICS

11097 OD Balancing aging mechanisms in organic field-effect transistors (Invited Paper) [1 1097-11]

POSTER SESSION

11097 OW Lateral confinement effect on crystallization behavior of a small molecule semiconductor during capillary force lithography for use in OFETs [1 1097-31] 
Proc. of SPIE Vol. 11097 1109701-4 Downloaded From: https://www.spiedigitallibrary.org/conference-proceedings-of-spie on 26 Apr 2023
Terms of Use: https://www.spiedigitallibrary.org/terms-of-use 


\title{
Authors
}

Numbers in the index correspond to the last two digits of the seven-digit citation identifier (CID) article numbering system used in Proceedings of SPIE. The first five digits reflect the volume number. Base 36 numbering is employed for the last two digits and indicates the order of articles within the volume. Numbers start with 00, 01, 02, 03, 04, 05, 06, 07, 08, 09, 0A, 0B...0Z, followed by 10-12, 20-2Z, etc.

\author{
An, Tae Kyu, OW \\ Chung, Seungjun, 07 \\ Fuentes-Hernandez, Canek, OD \\ Jeong, Inho, 07 \\ Jia, Xiaojia, OD \\ Kim, G., OD \\ Kippelen, Bernard, OD \\ Kwon, Hyeok-jin, OW \\ Park, Youngrak, OD \\ Wang, Cheng-Yin, OD
}


Proc. of SPIE Vol. 11097 1109701-6 Downloaded From: https://www.spiedigitallibrary.org/conference-proceedings-of-spie on 26 Apr 2023
Terms of Use: https://www.spiedigitallibrary.org/terms-of-use 


\section{Conference Committee}

Symposium Chairs

Zakya H. Kafafi, Lehigh University (United States)

Ifor D.W. Samuel, University of St. Andrews (United Kingdom)

Conference Chairs

Iain McCulloch, King Abdullah University of Science and Technology (Saudi Arabia)

Oana D. Jurchescu, Wake Forest University (United States)

\section{Session Chairs}

1 Organic Transistors in Sensing and Bioelectronics: Joint Session with Conferences 11096 and 11097

Oana D. Jurchescu, Wake Forest University (United States)

2 OFETS

Natalie Stingelin, Georgia Institute of Technology (United States)

3 Chemistry: Microstructure

lain McCulloch, King Abdullah University of Science and Technology (Saudi Arabia)

4 Device Physics

Thomas Anthopoulos, King Abdullah University of Science and Technology (Saudi Arabia)

5 Processing

Emily G. Bittle, National Institute of Standards and Technology (United States)

6 Fundamental Properties

Aram Amassian, North Carolina State University (United States)

7 Materials and Devices I

Andrew Wadsworth, Imperial College London (United Kingdom)

8 Materials and Devices II

Sahika Inal, King Abdullah University of Science and Technology (Saudi Arabia) 
Proc. of SPIE Vol. 11097 1109701-8 Downloaded From: https://www.spiedigitallibrary.org/conference-proceedings-of-spie on 26 Apr 2023
Terms of Use: https://www.spiedigitallibrary.org/terms-of-use 